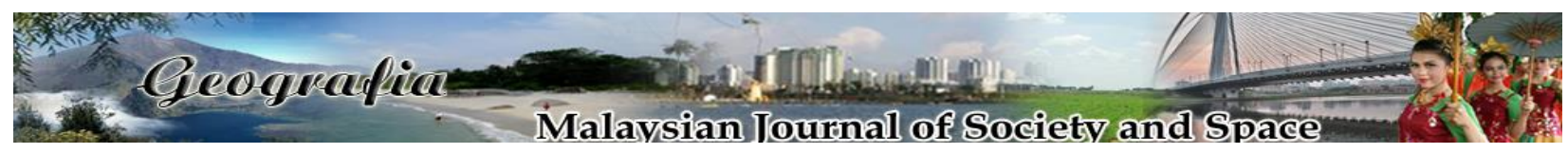

\title{
Aplikasi enam dimensi kelompok minoriti berdasarkan pendekatan Kinloch: Perubahan sosio-politik minoriti Rohingya
}

\author{
Noor Farhana Ahmad Pazil \\ Centre for Fundamental Studies, Management \& Science University, Shah Alam, Selangor \\ Correspondence: Noor Farhana Ahmad Pazil (email: noor_farhana@msu.edu.my)
}

Received: 01 October 2020; Accepted: 24 November 2020; Published: 29 November 2020

\begin{abstract}
Abstrak
Kehidupan golongan pelarian di negara penerima telah menyebabkan mereka berhadapan dengan pelbagai reaksi daripada masyarakat majoriti. Kajian ini memfokuskan pada minoriti Rohingya yang menetap di Malaysia. Operasi penghapusan etnik di Myanmar telah menyebabkan pengusiran berlaku dalam kalangan Rohingya dan mengakibatkan mereka digelar dengan pelbagai identiti seperti pelarian, pemohon suaka, golongan tanpa negara, orang hanyut serta etnik minoriti. Penindasan tehadap Rohingya di Myanmar telah menyebabkan kemunculan etnik ini di Malaysia menerusi migrasi secara besar-besaran bermula pada tahun 1978. Minoriti Rohingya secara umumnya dikategorikan sebagai golongan pelarian di Malaysia. Oleh itu, mereka berhadapan dengan undang-undang yang telah digariskan oleh kerajaan terhadap golongan pelarian. Sehingga hari ini, UNHCR (2020) mencatatkan anggaran 101,010 pelarian Rohingya yang telah mendaftar di Malaysia. Kajian ini akan merungkaikan hubungan antara masyarakat tempatan dan minoriti Rohingya di Selayang, Selangor dengan mengaplikasikan enam dimensi kelompok minoriti berdasarkan pendekatan Kinloch (1979). Kaedah kualitatif telah digunakan iaitu dengan menemu bual empat orang lelaki dan dua orang wanita etnik Rohingya di Selayang serta rujukan data sekunder daripada kajian perpustakaan seperti buku, jurnal, tesis, keratan akhbar dan data atas talian. Hasil kajian menunjukkan bahawa berlakunya sekatan dalam mendapatkan faedah dalam institusi terpenting seperti pekerjaan, pendidikan, serta kesihatan. Namun, kewujudan gerakan-gerakan sosial yang membantu golongan pelarian khususnya Rohingya dalam pelbagai aspek telah memberi ruang untuk minoriti ini meneruskan kelangsungan kehidupan di negara penerima. Interaksi yang baik antara kelompok majoriti dan minoriti Rohingya juga membantu mereka dalam beradaptasi dengan kehidupan di Malaysia.
\end{abstract}

Kata kunci: gerakan sosial, kelompok minoriti, migrasi, pelarian, perubahan sosio-politik, Rohingya 


\title{
Application of six dimensions of minority group based on Kinloch approach: The socio-political change of Rohingya minority
}

\begin{abstract}
The survival of the refugees in the host society caused them to face the reactions and acceptance of the majority ethnics. This study focuses on the Rohingya minority group residing in Malaysia. The ethnic cleansing operation in Myanmar has resulted in the expulsion of the Rohingya and resulting in various identities such as refugees, asylum seekers, stateless people, boat people and ethnic minorities. The suppression of the Rohingya in Myanmar has led to a massive migration starting from 1978 in Malaysia. The Rohingya minority group is generally categorised as refugees in Malaysia. Therefore, they need to adhere to the laws that has been outlined by the governments for the refugees. UNHCR (2020) recorded an estimate of 101,010 of Rohingya refugees who had registered in Malaysia. This study will discover the relationship between the local community and Rohingya minority group in Selayang, Selangor by applying six dimensions of minority group based on Kinloch (1979) approach. The qualitative method was used through in-depth interview session with four Rohingya men and two Rohingya women in Selayang. The secondary sources from previous studies was referred such as books, journals, theses, newspaper articles and online data. The results showed that there was a restriction in the most important institutions such as employment, education, and health. However, the existence of social movements that help the refugees in various aspects have provided an opportunity for the Rohingya minority group to continue their survival in the host society. Good interaction between the majority group and Rohingya minority group can also support them in an adaptation of life in Malaysia.
\end{abstract}

Keywords: social movement, minority group, migration, refugee, socio-political changes, Rohingya

\section{Pengenalan}

Kelompok minoriti merupakan kumpulan yang bilangannya kecil daripada populasi kelompok majoriti dalam sesebuah masyarakat (Kinloch, 1979). Kinloch meletakkan kelompok minoriti etnik dan ras dalam satu bahagian iaitu minoriti budaya kerana minoriti etnik dan ras adalah berkaitan antara satu sama lain. Golongan elit telah mendefinisikan minoriti budaya sebagai kumpulan yang berbeza dan mempunyai ciri-ciri budaya yang dianggap rendah serta dijadikan sebagai subjek kawalan dan diskriminasi. Little dan McGivern (2012) mentakrifkan etnik sebagai kumpulan manusia yang berkongsi kebudayaan yang sama iaitu merangkumi amalan, nilai, kepercayaan, bahasa, agama, dan tradisi. Dalam kajian ini pemilihan kelompok etnik dan ras adalah berdasarkan kepada isu penolakan kelompok majoriti terhadap golongan minoriti pelarian atau pendatang tanpa izin. Perubahan keadaan sosiopolitik yang berlaku selepas migrasi ke negara baharu telah menyebabkan golongan minoriti mengalami kesukaran dalam meneruskan kehidupan. Dalam memahami perkembangan kelompok minoriti etnik, pengkaji memilih untuk mengkaji minoriti pelarian Rohingya di Selayang. Kajian ini mengaplikasikan enam dimensi kelompok minoriti iaitu dengan melihat sejarah kemunculan kelompok minoriti, 
ciri-ciri demografi minoriti, sikap minoriti dan majoriti, keinstitusian, gerakan-gerakan sosial serta hubungan utama yang terhasil daripada interaksi kelompok minoriti dan majoriti. Pendekatan ini dikemukakan oleh Kinloch (1979) untuk memahami sesebuah kelompok minoriti dengan lebih terperinci.

\section{Sorotan karya}

Pelarian merupakan minoriti etnik yang berhijrah ke negara baharu disebabkan oleh beberapa faktor. Antara faktor berikut ialah mereka diusir dari negara asal dan desakan hidup. Etnik Rohingya misalnya dapat dikategorikan sebagai pelarian (refugee), pemohon suaka (asylum seeker) dan pendatang asing tanpa izin (PATI). Pelarian merupakan individu yang tinggal di luar negara dan tidak dapat kembali ke negara asal kerana takut dengan penganiayaan terhadap diri mereka disebabkan oleh bangsa, agama, kewarganegaraan, pandangan politik atau kelompok sosial. Pemohon suaka pula ialah individu yang melarikan diri dari negaranya dan memohon untuk perlindungan sebagai pelarian di negara yang diduduki. Manakala pendatang asing tanpa izin merupakan individu yang berada dalam negara dengan keadaan tanpa kebenaran rasmi untuk berada di negara tersebut. Mereka juga merupakan golongan minoriti di negara penerima. Malah, terdapat juga pelarian yang menerima layanan berbeza disebabkan oleh ketiadaan dokumen yang sah.

Kajian yang dijalankan oleh Schweitzer et al. (2005) menunjukkan sikap negatif yang dipaparkan oleh golongan majoriti di Australia terhadap golongan pelarian. Hasil kajian menunjukkan 59.8 peratus responden mempunyai sikap prejudis yang tinggi terhadap pelarian termasuklah kebencian dan permusuhan (Schweitzer et al., 2005). Malah, terdapat beberapa hujah yang menyatakan bahawa warganegara Australia terutamanya yang berkulit putih mempunyai sikap prejudis dan rasis terhadap kelompok minoriti yang terdapat di sana iaitu minoriti pribumi dan pelarian-pelarian Asia (Beswick \& Hills, 1972; Walker, 1994). Mereka beranggapan bahawa jumlah pendatang asing tanpa izin harus dikurangkan. Kajian ini juga menunjukkan minoriti Timor Leste menghadapi diskriminasi ras apabila dimalukan di tempat awam, pasar raya serta di tempat kerja kerana warna kulit dan loghat pertuturan yang berlainan daripada kelompok majoriti Australia. Diskriminasi secara lisan khususnya telah dicetuskan oleh kelompok majoriti, rakan sekerja dan masyarakat setempat. Sikap prejudis dan rasis yang dirasai oleh minoriti Timor Leste memberikan kesan negatif terhadap diri dan penglibatan mereka dalam masyarakat (Human Rights and Equal Opportunity Commission, 1999).

Pengalaman golongan minoriti dalam menghadapi kehidupan sebagai pelarian dan pemohon suaka mengingatkan mereka mengenai ketidakstabilan politik, penentangan, serta kehilangan kaum keluarga dan rakan-rakan. Kajian oleh Askland (2007) terhadap minoriti Timor Leste menunjukkan bahawa kebanyakan mereka pada mulanya bersikap mengasingkan diri (alienated) daripada kehidupan baharu mereka di Australia kerana trauma yang dialami. Perubahan sosial yang berlaku menyebabkan mereka menghadapi kesukaran dalam menyesuaikan diri dengan kepelbagaian budaya yang terdapat di Australia. Malah, segelintir daripada mereka mengalami kejutan budaya, masalah dalam berkomunikasi, kesunyian, dan rasa terasing (Askland 2007). Walau bagaimanapun, selepas tempoh trauma, kelompok Timor Leste mula berinteraksi dengan rakyat tempatan dan cuba berasimilasi dengan budaya Australia terutamanya bertutur dalam bahasa pengantar dan juga menyesuaikan diri dengan persekitaran 
baharu. Askland (2007) juga menjelaskan bahawa golongan muda Timor Leste lebih mudah dilentur serta bersifat terbuka dalam menerima perubahan sosiopolitik dan budaya di Australia.

Dalam institusi pendidikan, terdapat negara yang membenarkan anak-anak pelarian mendapat pendidikan formal di sekolah. Misalnya di Australia, sistem persekolahan dan guruguru telah memberikan sokongan dan galakan kepada anak-anak pelarian dalam mengharungi kehidupan baharu dengan menyediakan kemudahan pendidikan bahasa yang merupakan aspek terpenting dalam budaya (Hyman et al., 2000). Hasilnya, anak-anak pelarian dapat berinteraksi dengan masyarakat, memupuk keyakinan diri serta rasa milik bersama. Malah, sebilangan besar berjaya menamatkan pengajian di peringkat diploma dan sijil vokasional. Penguasaan bahasa, pengadaptasian budaya serta kelayakan akademik yang diperolehi telah melayakkan mereka mendapat pekerjaan dalam bidang yang lebih khusus (Hyman et al., 2000). Minoriti pelarian mengalami kesukaran untuk menyambung pelajaran di universiti awam dan mendapat tajaan daripada kerajaan. Namun, terdapat sebilangan kecil anak-anak pelarian mendapat pendidikan di universiti sebagai pelajar antarabangsa tanpa diberikan sebarang tajaan dan mereka dikehendaki membayar yuran penuh (Rees, 2004). Oleh itu, dalam sistem pendidikan di Australia hanya 12.3 peratus anak-anak pelarian yang memegang kelayakan diploma atau kelayakan tertinggi dan hanya 8.6 peratus mempunyai kelayakan sijil (Australian Government Department of Immigration and Citizenship, 2006).

Malah, laporan oleh Pikkarainen dan Brodin (2008) menerangkan diskriminasi yang dihadapi oleh minoriti etnik di Sweden berlaku dalam aspek pendidikan. Walaupun kelompok minoriti dibenarkan memasuki sekolah awam, namun mereka masih menjadi mangsa serangan di sekolah serta menghadapi diskriminasi dari segi pembelajaran bahasa dan budaya. Malah, sejak penghujung abad ke-19 polisi asimilasi bahasa telah diperkenalkan di Sweden yang telah menyekat kelompok minoriti daripada mempelajari bahasa ibunda dan budaya mereka. Keadaan ini telah menyukarkan mereka untuk mengekalkan jati diri etnik mereka. Pikkarainen dan Brodin (2008) turut menyatakan bahawa sistem pendidikan yang diterima oleh minoriti etnik di Sweden tidak memberi penekanan terhadap kepentingan bahasa, identiti dan budaya. Kelompok minoriti juga dijadikan sebagai bahan jenaka dalam buku teks dan bahan bacaan di sekolah yang menyebabkan penindasan yang berterusan terhadap minoriti etnik di Sweden.

Crockford (2007) juga menyatakan bahawa kelompok pelarian berada dalam kesusahan kerana kekurangan peluang pekerjaan. Hal ini berikutan daripada alasan majikan yang hanya menerima penduduk tetap sebagai pekerja. Oleh itu, kebanyakan golongan pelarian tidak mendapat pekerjaan yang tetap. Mereka hanya diberi pekerjaan berkemahiran rendah dan bergaji rendah. Natijahnya, golongan pelarian berisiko untuk kekal berada dalam lingkungan kemiskinan. Bilangan buruh paksa dalam kalangan pelarian adalah pada tahap yang membimbangkan kerana hal ini turut melibatkan golongan remaja berumur 15 tahun ke atas. Pendapatan mingguan mereka juga adalah lebih rendah iaitu sebanyak $\$ 422$ berbanding rakyat Australia iaitu sebanyak $\$ 488$ seminggu (Australian Government Department of Immigration and Citizenship, 2006). Minoriti pelarian juga kurang menerima perlindungan daripada sistem anugerah dan undang-undang untuk menjamin hak-hak individu (Human Rights and Equal Opportunity Commission, 1999). Sebahagian mereka menderita dengan segregasi pekerjaan disebabkan oleh tiada pengiktirafan kelayakan bekerja, kurang kemahiran dan pengalaman. 


\section{Kaedah kajian}

Kajian ini menggunakan enam dimensi kelompok minoriti yang diperkenalkan oleh Kinloch (1979). Dalam merungkaikan pendekatan Kinloch, beberapa buah keluarga etnik Rohingya di Selayang telah dijadikan sebagai populasi kajian. Pengkaji menggunakan kaedah persampelan bertujuan, iaitu dengan memilih empat orang lelaki dan dua orang wanita etnik Rohingya berdasarkan kriteria berikut iaitu telah berkahwin, mempunyai pekerjaan dan mempunyai anak yang masih bersekolah. Kaedah kualitatif yang digunakan termasuklah kaedah temu bual secara mendalam. Kaedah ini digunakan untuk mengambil kira pandangan, pendapat dan pengalaman mereka sebagai golongan minoriti di Malaysia. Pengkaji juga mengambil pandangan kajian terdahulu sebagai rujukan utama iaitu data sekunder daripada jurnal, buku, tesis dan sumber atas talian. Kajian ini menggunakan analisis tema berdasarkan enam tema utama iaitu, 1) sejarah kemunculan kelompok minoriti, 2) ciri-ciri demografi minoriti, 3) sikap minoriti dan majoriti, 4) kawalan keinstitusian, 5) gerakan-gerakan sosial serta 6) hubungan utama yang terhasil daripada interaksi kelompok minoriti dan majoriti. Selain itu, hasil dapatan temu bual pula dianalisis menggunakan kaedah analisis naratif. Profil informan yang terlibat dalam kajian ini dirumuskan dalam Jadual 1.

Jadual 1. Profil Informan

\begin{tabular}{cccc}
\hline Informan & Umur & Pendapatan & Bilangan Anak \\
\hline Encik Adam & 40 tahun & RM 1,500 & 5 \\
Encik Badri & 31 tahun & RM 600 & 2 \\
Encik Hamzah & 35 tahun & RM 500 & 2 \\
Encik Taufiq & 47 tahun & RM 180 & 1 \\
Puan Jameela & 25 tahun & RM 1,200 & 2 \\
Puan Safiya & 48 tahun & RM 900 & 2 \\
\hline
\end{tabular}

\section{Dapatan kajian dan perbincangan}

\section{Sejarah kemunculan kelompok minoriti Rohingya di Malaysia}

Berdasarkan idea Kinloch, perkara asas yang perlu dilihat untuk memahami kelompok minoriti ialah sejarah kemunculan mereka di negara penerima. Rohingya merupakan minoriti etnik yang berasal dari negeri Arakan atau Rakhine di Myanmar (Burma). Kelompok etnik ini tertumpu di tiga buah bandar di sebelah utara Arakan dan bersebelahan negara Bangladesh. Etnik Rohingya lebih dikenali sebagai golongan pelarian atau golongan "tanpa negara" oleh pertubuhanpertubuhan antarabangsa dan tempatan (Suan, 2006). Mereka juga digelar sebagai orang hanyut atau "boat people". Menurut International Rescue Committee (2018), etnik Rohingya dikaitkan dengan masyarakat Bengali Chittagonian yang mengamalkan Islam Sunni dan menetap di sempadan Bangladesh. Kerajaan Myanmar tidak mengiktiraf kerakyatan kelompok Rohingya kerana mendakwa Rohingya adalah sebahagian masyarakat Bengali. Hal ini diputuskan menerusi Undang-undang Kewarganegaraan Myanmar 1982, iaitu dengan melucutkan kewarganegaraan Rohingya di Myanmar dan menjadikan mereka sebagai kelompok yang tiada kerakyatan di Myanmar.

Status sebagai golongan tanpa negara (stateless) ini telah menyebabkan diskriminasi secara berterusan terhadap minoriti Rohingya ini sehingga tercetusnya operasi penghapusan etnik 
pada 18 Julai 1991 (Dali \& Abdullah, 2012). Hal ini telah menyebabkan kemusnahan kediaman, rumah ibadat, sekatan dari segi pendidikan, kesukaran dalam mendapat peluang pekerjaan serta operasi pembunuhan beramai-ramai. Minoriti Rohingya menjalani kehidupan baharu sebagai golongan pelarian di negara yang berdekatan dengan negara Myanmar kerana takut untuk meneruskan kehidupan di Rakhine. Terdapat juga di antara mereka yang diusir dari negara Myanmar dan menjalani kehidupan secara diaspora di negara-negara lain seperti Malaysia, Bangladesh, negara Arab dan beberapa negara Asia yang lain (Suan, 2006). Menurut International Rescue Committee (2018), pelucutan kewarganegaraan Rohingya di Myanmar dan penindasan yang berlaku pada tahun 1990 telah membawa kepada penghijrahan lebih kurang satu setengah juta etnik Rohingya dari Myanmar ke Bangladesh dan 14,000 lagi ke Malaysia. Mereka tiada pilihan selain bergantung kepada migrasi secara haram, menjadi mangsa penyeludupan, buruh paksa serta menjalani perjalanan dalam perahu yang berisiko (Lewa, 2009). Kemunculan minoriti Rohingya di Malaysia bermula daripada gelombang kedua migrasi beramai-ramai yang melibatkan anggaran 220,000 pelarian Rohingya pada tahun 1978 ke Bangladesh, Malaysia dan Thailand (Wahab, 2013). Menurut salah seorang informan di Selayang;

Penghijrahan saya ke Malaysia adalah bertujuan untuk menjamin keselamatan keluarga dan mengubah masa depan anak-anak.

Sumber: Encik Badri (lelaki, 31 tahun)

Manakala, informan yang lain iaitu Encik Taufiq menyatakan bahawa tujuan penghijrahan beliau ke Malaysia adalah untuk menyelamatkan diri.

Pada tahun 1991, bandar kami dimasuki askar Myanmar. Rumah kami telah dipecah masuk. Kami dilarang daripada memasuki masjid. Apabila saya dan tiga kawan cuba memasuki masjid, dua orang kawan saya telah ditangkap oleh askar. Saya dan seorang lagi kawan saya telah melarikan diri ke Malaysia untuk menyelamatkan diri.

Sumber: Encik Taufiq (lelaki, 47 tahun)

\section{Ciri-ciri demografi minoriti Rohingya di Malaysia}

Dimensi kedua yang ditekankan oleh Kinloch adalah ciri-ciri demografi minoriti etnik. Mengikut perundangan Malaysia, kelompok Rohingya masih dianggap sebagai "pendatang izin tanpa izin". Namun pada akhir tahun 2004, kerajaan Malaysia mengambil sikap positif untuk menerima kelompok Rohingya sebagai "pelarian" (Suan, 2006). Bilangan pelarian Rohingya masih meningkat di Malaysia kerana mereka tidak diterima apabila ditangkap dan dipulangkan semula ke Myanmar. Malah, kemunculan semula kelompok minoriti ini di Myanmar menyebabkan penganiayaan secara berterusan. Menurut Suan (2006), anggaran populasi Rohingya di Malaysia pada tahun 1998 adalah sebanyak 5,000 penduduk. Bilangan Rohingya di Malaysia semakin meningkat sehingga tahun 2005 dengan anggaran populasi sebanyak 10,000 hingga 35,000 penduduk (Suan, 2006). Taburan geografi menunjukkan kebanyakan kelompok Rohingya menetap di Pulau Pinang dan Kuala Lumpur, manakala sebilangan kecil menetap di Johor, Melaka, Kedah, Kelantan, Terangganu dan Negeri Sembilan (Future Global Network 2009, The Equal Rights Trust, 2010). Kini, anggaran populasi pelarian Myanmar termasuk etnik Rohingya 
adalah sebanyak 154,080 orang penduduk (rujuk Jadual 2). Sehingga bulan Februari 2020, United Nations High Commissioner for Refugees atau UNHCR (2020) mencatatkan sebanyak 68 peratus pelarian lelaki daripada negara Myanmar, manakala 32 peratus merupakan pelarian wanita. Menurut Human Right Watch (2000), majoriti komuniti Rohingya menetap di Lembah Klang terutamanya di sekitar Ampang, Klang dan Selayang. Kelompok Rohingya di Selayang hidup secara berkongsi dalam kediaman dan kejiranan yang sama. Hal ini disebabkan oleh sumber pendapatan yang terhad dan mereka sukar untuk bertahan sekiranya hidup secara berasingan. Berdasarkan kajian yang dilakukan di Selayang, penghijrahan minoriti Rohingya ke Malaysia dimulakan oleh golongan lelaki sejak tahun 1990-an. Mereka kemudiannya pulang semula ke Myanmar demi menyelamatkan ahli keluarga yang lain terutamanya isteri dan anakanak. Salah seorang informan berkata;

Suami saya sudah lama bekerja di Malaysia dan beliau ada kad UNHCR. Saya tinggal di Rakhine tetapi di sana keadaan tidak selamat. Saya kemudiannya berhijrah ke Malaysia mengikut suami. Kami menaiki kereta dari Rakhine sehingga sampai ke Thailand dan kemudian kami teruskan perjalanan masuk ke Malaysia.

Sumber: Puan Safiya (wanita, 48 tahun)

Jadual 2. Populasi pelarian Myanmar yang mendaftar di UNHCR Malaysia pada penghujung bulan Februari 2020 dalam UNHCR (2020)

\begin{tabular}{lll}
\hline No & Etnik & Bilangan Populasi \\
\hline 1. & Chin & 22,810 \\
2. & Rohingya & 101,010 \\
3. & Lain-lain & 30,250
\end{tabular}

Sumber: UNHCR (2020)

\section{Sikap minoriti dan majoriti}

Dimensi Kinloch seterusnya adalah untuk memahami sikap minoriti dan majoriti. Menurut Kinloch (1979), kelangsungan kehidupan kelompok minoriti dipengaruhi oleh sikap dan pandangan kelompok majoriti terhadap mereka dan sebaliknya. Pengkaji mendapati bahawa sikap segregasi dan prejudis terhadap kelompok minoriti Rohingya bukan sahaja berlaku di Myanmar, malah turut berlaku di Malaysia. Rejim tentera Myanmar menjadikan mereka sebagai buruh paksa, merampas tanah, serta melakukan penganiayaan dan kekejaman terhadap minoriti Rohingya (Medecins Sans Frontieres, 2002). Hal ini disebabkan oleh ciri-ciri bertentangan yang dimiliki oleh minoriti Rohingya iaitu warna kulit dan agama yang dianuti. Golongan majoriti meletakkan kelompok minoriti di kedudukan yang terendah atau "inferior" berbanding mereka. Malah, aktiviti mengemis dalam kalangan Rohingya di Malaysia yang turut melibatkan golongan kanak-kanak turut menjadi isu yang perlu diselesaikan kerana kelompok majoriti menganggap mereka memburukkan imej dan maruah negara. Kebimbangan golongan majoriti terhadap penguasaan etnik Rohingya yang menjual secara kecil-kecilan di kawasan pasar turut menimbulkan perasaan prejudis dan stereotaip terhadap kualiti dan kebersihan bahan makanan tersebut (Suan, 2006). Golongan majoriti juga sering bersikap stereotaip terhadap anak-anak minoriti Rohingya yang dianggap sebagai kurang intelek berbanding anak-anak mereka. 
Golongan majoriti bersikap sedemikian tanpa mengetahui bahawa berlakunya segregasi dan diskriminasi pendidikan kerana anak-anak etnik Rohingya tidak dibenarkan mengikuti pendidikan formal di Malaysia.

Sikap stereotaip, segregasi dan prejudis kelompok majoriti terhadap etnik Rohingya telah menjadikan mereka bangkit menggunakan pelbagai alternatif baru seperti berakulturasi dengan budaya majoriti, mengaplikasi kaedah rawatan tradisional, berniaga secara kecil-kecilan serta berwaspada dari segi keselamatan kerana bimbang akan ditangkap serta dihantar ke sempadan Malaysia. Bagi meneruskan kehidupan di Selayang, mereka cuba beradaptasi dengan corak kehidupan di Malaysia. Kekurangan dalam mendapatkan keperluan asas pendidikan dan pekerjaan tidak memutuskan semangat mereka. Minoriti Rohingya di Selayang sangat akrab dan mereka juga bergantung antara satu sama lain. Malah, menurut salah seorang informan;

Kami tinggal bersama dan berjiran. Kami sentiasa berkongsi masalah dan selalu mengambil berat antara satu sama lain. Kadangkala kami juga berbincang terutamanya untuk selesaikan masalah pendidikan anak-anak.

Sumber: Encik Taufiq (lelaki, 47 tahun)

\section{Kawalan keinstitusian}

Dimensi keempat yang diperkenalkan oleh Kinloch adalah kawalan keinstitusian terhadap kelompok minoriti. Institusi utama yang difokuskan oleh beliau ialah politik, sosial dan ekonomi. Pelarian Rohingya jelas dikawal oleh institusi terutamanya dalam sektor ekonomi, perkhidmatan dan sumber, politik, pendidikan, dan undang-undang. Hal ini telah menjadikan kehidupan minoriti Rohingya terdera dengan kawalan ini. Mengikut perundangan Malaysia, minoriti Rohingya dianggap sebagai "pelarian". Permasalahan utama dalam kalangan Rohingya ialah ketiadaan rekod atau dokumen kerakyatan yang sah di Malaysia. Malaysia masih tidak menerima golongan pelarian kerana belum menandatangani Konvensyen Pelarian 1951 (Suan, 2006). Hasil kajian menunjukkan bahawa lima orang informan di Selayang mempunyai kad UNHCR, manakala seorang informan masih dalam proses permohonan. Namun, menurut salah seorang daripada informan, kad UNHCR ini kurang diakui sah kerana mereka masih menghadapi kesulitan dalam pelbagai insitusi di Malaysia. Misalnya, mereka menghadapi kesulitan dalam mendapat pendidikan formal, pekerjaan dalam sektor awam, rawatan di hospital awam dan sebagainya. Kemelut ini berlaku secara berterusan terhadap generasi kedua Rohingya yang dilahirkan di Malaysia yang sukar untuk memperoleh sijil kelahiran kerana ibu bapa tidak mempunyai sebarang dokumen pengenalan diri.

Selain itu, institusi pendidikan turut mengawal anak-anak Rohingya untuk mendapat pendidikan formal di sekolah awam. Anak-anak etnik Rohingya hanya mempunyai peluang yang tipis dalam pembelajaran. UNHCR menganggarkan bahawa sebanyak 80 peratus bilangan anakanak Rohingya tidak mendapat pendidikan formal di sekolah awam kerana berlaku segregasi dalam pendidikan. Terdapat sebilangan kecil mendapat pendidikan tidak formal di sekolah badan bukan kerajaan atau sekolah komuniti yang tidak diiktiraf oleh kerajaan, sekolah agama atau tuisyen. Menurut Yoshikawa dan Teff (2011), pembelajaran tidak formal ini tidak dapat menjamin kehidupan mereka pada masa hadapan kerana mereka hanya diajar mata pelajaran agama dan bahasa Inggeris. Terdapat beberapa buah sekolah badan bukan kerajaan yang menyediakan beberapa mata pelajaran lain, namun menghadapi kekurangan sumber dan guru yang bertauliah (Yoshikawa \& Teff, 2011). Selain itu, lokasi sekolah komuniti yang jauh dari 
rumah turut menimbulkan kebimbangan dalam kalangan ibu bapa etnik Rohingya sekiranya anak-anak mereka ditahan oleh pihak berkuasa. Minoriti Rohingya juga telah menyekat anakanak perempuan untuk pergi ke sekolah untuk melindungi keselamatan mereka (UNDP, 2018). Berdasarkan kajian di Selayang menunjukkan kebanyakan anak-anak etnik Rohingya hanya mampu bertutur dalam bahasa Melayu tetapi tidak tahu menulis dan membaca.

Kajian International Rescue Committee (2020) terhadap pendidikan anak-anak Rohingya di Bangladesh menunjukkan peluang pendidikan juga adalah terhad kerana golongan remaja tidak berpeluang untuk melanjutkan pelajaran di sekolah menengah. Manakala hasil kajian di Selayang menunjukkan golongan remaja tiada pilihan selain daripada mengulangi pembelajaran tahap sekolah rendah. Terdapat juga anak-anak pelarian di Malaysia yang tidak bersekolah dan terlibat dalam jenayah mencuri serta mengemis (Kassim, 2009). Sindiket meminta sedekah yang berleluasa di Pulau Pinang dan di daerah Klang adalah disebabkan oleh ketiadaan peluang untuk mendapatkan pendidikan formal di sekolah. Kajian Skeels (2012) di Uganda menunjukkan pemberian hak pendidikan bagi anak-anak pelarian dapat melindungi mereka daripada terlibat dalam sindiket buruh kanak-kanak. Oleh itu, ilmu dan kemahiran amat penting dan dapat mengubah masa hadapan anak-anak pelarian.

Isu pengangguran dalam kalangan Rohingya masih tinggi berikutan daripada kekangan peluang pekerjaan serta ketiadaan dokumen kerakyatan yang sah mahupun permit kerja. Selain itu, sesetengah majikan mengenepikan golongan Rohingya dalam pemilihan pekerja kerana tidak mahu mengambil risiko dikenakan tindakan undang-undang oleh pihak berkuasa sekiranya mengambil pendatang asing tanpa izin. Minoriti Rohingya tidak memperoleh jaminan insuran, kesihatan dan cuti bergaji (Dali \& Abdullah, 2012). Malah, terdapat sebahagian majikan yang mengeksploitasi serta mendominasi golongan Rohingya dengan hanya memberikan pekerjaan tidak mahir dengan gaji yang rendah kepada mereka. Disebabkan oleh kekangan peluang pekerjaan, maka sosioekonomi kelompok Rohingya adalah bergantung sepenuhnya kepada kaum lelaki terutamanya ketua keluarga. Wanita Rohingya lebih banyak melakukan kerja rumah dan bergantung kepada gaji suami sepenuhnya. Walau bagaimanapun, terdapat sebilangan wanita yang berniaga secara kecil-kecilan di tepi jalan. Selain itu, anak lelaki turut menyara keluarga dengan melakukan kerja tidak mahir seperti memotong rumput dan memungut sampah (International Rescue Committee, 2018). Masalah ini menyebabkan paras kemiskinan yang kian meruncing dalam kalangan minoriti Rohingya.

Hasil kajian di Selayang ini juga menunjukkan bahawa minoriti Rohingya kurang berkemahiran untuk bekerja dalam sektor pembinaan bangunan seperti pekerja asing yang lain. Oleh itu, terdapat sebilangan kecil sahaja yang berkecimpung dalam sektor tersebut. Kebanyakan minoriti Rohingya mempunyai gaji paling minimum berbanding pekerja asing yang lain kerana mereka bekerja sebagai pemotong rumput, peniaga kuih muih, penyusun sayur-sayuran di pasar, serta sebagai pemungut sampah. Pengkaji juga mendapati bahawa hasil pendapatan harian adalah dalam lingkungan RM6 hingga RM50. Pendapatan bulanan yang terendah adalah sebanyak RM180, manakala pendapatan bulanan seisi rumah yang paling tinggi bagi informan ialah sebanyak RM1,500 (rujuk Rajah 1). Gaji bulanan yang tinggi ini adalah disebabkan oleh mereka berkerja sebagai pekerja kilang dan buruh binaan. 


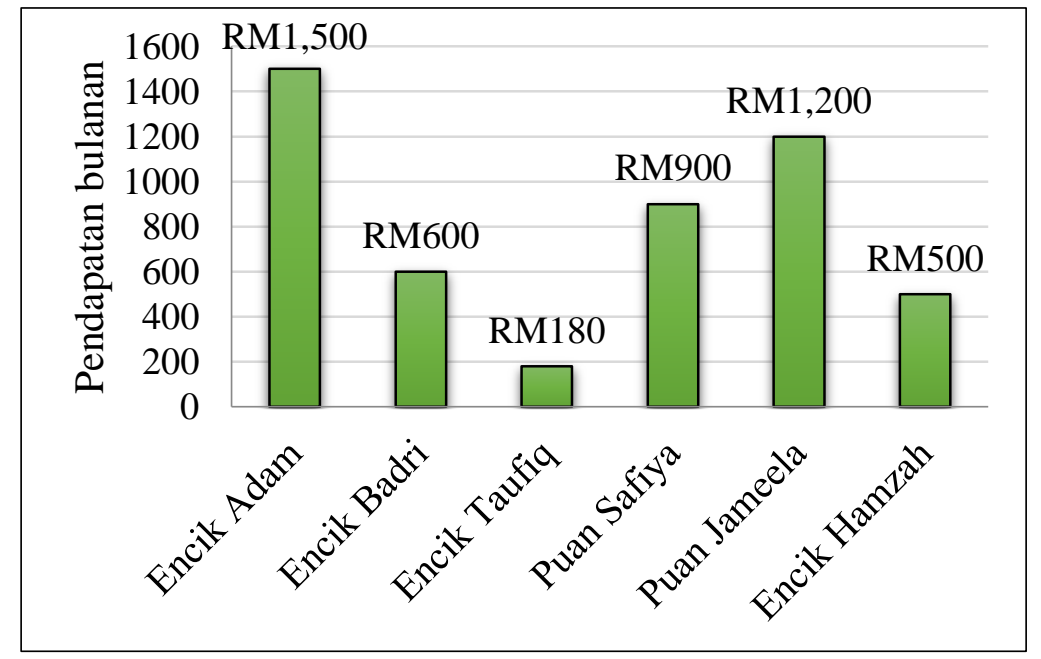

Rajah 1: Pendapatan bulanan seisi rumah informan

Selain itu, kesukaran dalam mendapatkan rawatan kesihatan turut dialami oleh kelompok Rohingya disebabkan oleh masalah dokumen dan kos rawatan yang tinggi. Menurut Suan (2006), dalam sistem perubatan di Malaysia, kadar bayaran yang dikenakan terhadap warga asing adalah jauh lebih tinggi berbanding warganegara. Malah, terdapat satu kes seorang wanita Rohingya yang tidak dibenarkan masuk ke dalam wad bersalin dan dilayan dengan buruk oleh pekerja hospital telah dilaporkan (Suan, 2006). UNHCR pernah menyediakan perkhidmatan pantas (fasttrack) kepada wanita pelarian yang mengandung bagi membolehkan mereka mendapat rawatan kesihatan dengan harga yang rendah. Namun, perkhidmatan ini dihentikan oleh UNHCR kerana statistik menunjukkan desakan untuk mendapatkan rawatan dengan harga yang rendah telah meningkatkan kadar bilangan wanita mengandung (Yoshikawa \& Teff, 2011). Oleh itu, wanita mengandung menghadapi kesukaran mendapatkan rawatan. Selain itu, terdapat juga ugutan untuk menahan Rohingya sekiranya mendapatkan rawatan di hospital tempatan (The Equal Rights Trust, 2010). Hal ini menyebabkan mereka terbeban apabila ahli keluarga jatuh sakit dan juga ketika waktu bersalin. Oleh itu, mereka lebih cenderung menggunakan alternatif rawatan tradisional dalam merawat penyakit serta memilih untuk bersalin di rumah (Suan, 2006).

Minoriti Rohingya mendapat perhatian rakyat Malaysia pada tahun 2015 disebabkan oleh sindiket pemerdagangan manusia di Wang Kelian dan Padang Besar, Perlis serta Songkla, Thailand (Bernama, 2015). Minoriti Rohingya tersebut telah membayar sejumlah wang kepada agen yang terlibat untuk dibawa masuk melalui sempadan Thailand dan Malaysia. Pada Mei 2015, sindiket pemerdagangan Rohingya ini telah memberi kejutan besar kepada negara apabila pihak berkuasa telah menemui 35 orang mangsa pemerdagangan manusia yang ditanam di sempadan Thailand-Malaysia (Bernama, 2015). Kajian oleh Hamzah, Daud dan Idris (2016) menunjukkan kerjasama PDRM Malaysia dan kerajaan Thailand dalam membantu untuk mengawal kemasukan pelarian Rohingya yang berterusan sejak mereka diisytiharkan sebagai golongan tanpa negara (stateless) oleh kerajaan Myanmar pada tahun 1982. Golongan pelarian yang ditahan telah dipindahkan ke Depoh Tahanan Imigresen Belantik, Kedah. Pada bulan Oktober 2016 pula dunia telah digemparkan dengan operasi pembersihan etnik Rohingya yang dijalankan di Arakan oleh kerajaan Myanmar. Hal ini telah menyebabkan mereka cuba memasuki sempadan negara-negara berdekatan untuk menyelamatkan diri. Namun, kerajaan Malaysia menghadapi kesukaran dalam menampung jumlah pelarian dengan populasi Rohingya 
yang semakin meningkat setiap tahun. Keadaan ini menyebabkan pelarian Rohingya terdampar di tengah lautan dan hidup di atas bot besar.

Minoriti Rohingya menghadapi kesukaran di Malaysia kerana tiada dokumen kerakyatan yang sah. Kerajaan juga menjalankan operasi penangkapan dan penahanan pendatang asing tanpa izin termasuk minoriti Rohingya dan kemudiannya menghantar mereka pulang ke negara asal. Selain itu, beberapa undang-undang dan hukuman terhadap Rohingya dirangka supaya dapat mengawal kemasukan dan pergerakan kelompok minoriti ini dalam negara. Di bawah Akta Imigresen 1959/1963 Pindaan 2002, individu yang memasuki atau berada di Malaysia secara haram akan dikenakan dakwaan. Di samping itu, hukuman yang lebih ketat turut dikenakan untuk pendatang asing tanpa izin yang melakukan kesalahan dengan memperkenalkan hukuman sebat bagi pesalah kali pertama, didenda tidak melebihi RM10,000, dipenjara tidak melebihi lima tahun serta disingkirkan dari negara (The Equal Rights Trust, 2010). Keadaan pelarian yang ditahan dalam pusat penahanan imigresen adalah lebih teruk daripada penjara (Yoshikawa dan Teff, 2011). Tahanan menghadapi masalah makanan dan air yang tidak mencukupi, persekitaran yang tidak bersih, kepanasan melampau pada waktu siang dan kesejukan pada waktu malam di dalam bilik tahanan (Yoshikawa dan Teff, 2011). Sekiranya tahanan tidak mempunyai ahli keluarga atau rakan untuk memaklumkan UNHCR mengenai penahanan mereka, maka mereka tidak mendapat sokongan daripada UNHCR dan akan terus ditahan di pusat penahanan.

\section{Gerakan-gerakan sosial}

Seterusnya Kinloch menekankan dimensi gerakan-gerakan sosial yang terbentuk kesan daripada reaksi kelompok minoriti. Reaksi kelompok minoriti Rohingya terhadap kawalan kelompok majoriti sejak sekian lama telah membentuk gerakan-gerakan sosial agar nasib Rohingya terbela. Secara rasminya United Nations High Commissioner for Refugees (UNHCR) merupakan gerakan sosial utama yang membantu minoriti pelarian dan pemohon suaka di Malaysia. Selain itu, terdapat badan bukan kerajaan (NGO) dan pertubuhan antarabangsa yang turut membantu membela nasib pelarian Rohingya. Gerakan-gerakan ini ditubuhkan bagi menghulurkan bantuan kepada anggota minoriti Rohingya serta meringankan penderitaan mereka. Misalnya, The Equal Rights Trust (ERT), Rohingya Information Center (RIC), Ethnic Rohingya Human Rights Organisation (ERHRO), Rohingya Solidarity Democratic Movement (RSDM), United Nation Commisioner for Refugee (UNHRC), Human Right Watch (HRW), Amnesty International (AI), Pertubuhan Hak Asasi Untuk Rohingya (HURAR) serta Suara Rakyat Malaysia (SUARAM). Kesemua pertubuhan mempunyai matlamat yang sama iaitu membanteras diskriminasi dan mempromosi kesaksamaan sebagai hak asasi manusia serta prinsip asas keadilan sosial. Misalnya, Pertubuhan Hak Asasi Untuk Rohingya (HURAR) membantu dalam mengesan sindiket memperdayakan masjid dan surau dengan mengaut untung hasil daripada meraih simpati terhadap nasib pelarian Rohingya. Gerakan-gerakan ini mengemukakan beberapa cadangan yang dapat membantu golongan Rohingya menghadapi krisis kemiskinan serta membela nasib generasi kedua dalam menempuh kehidupan sebagai golongan tanpa negara (stateless).

Kajian ini menunjukkan bahawa Majlis Ulama Rohingya Malaysia (MUR) dan Future Global Network Foundation (FGN) merupakan gerakan sosial paling berpengaruh membantu komuniti Rohingya di Selayang dalam memperjuangkan pendidikan kepada anak-anak Rohingya. Majlis Ulama Rohingya Malaysia (MUR) ditubuhkan sendiri oleh komuniti Rohingya yang berperanan untuk menguruskan pengajian Islam berfahaman Mazhab Hanafi di sepuluh buah madrasah anak-anak Rohingya. MUR bertanggungjawab mencari dan merekod komuniti 
Rohingya yang baharu berhijrah ke Malaysia dalam usaha untuk membantu mereka beradaptasi dengan kehidupan di sini. Manakala FGN yang ditubuhkan pada tahun 2006 oleh warganegara Malaysia memperjuangkan hak asasi golongan pelarian di Malaysia termasuk Rohingya. Usaha mereka dalam membina sekolah swasta untuk golongan pelarian secara berperingkat di Malaysia telah memberi harapan baharu kepada minoriti Rohingya di Selayang.

\section{Hubungan utama yang terhasil daripada interaksi kelompok minoriti dan majoriti}

Dimensi terakhir yang diperkenalkan oleh Kinloch adalah hubungan utama yang terhasil daripada interaksi kelompok minoriti dan majoriti. Bahagian ini melihat kepada perubahan sosial yang berlaku hasil daripada interaksi atau hubungan antara kelompok minoriti dan majoriti. Dalam hubungan kelompok majoriti dan minoriti, penekanan terhadap kepentingan ekonomi adalah sangat dititikberatkan berikutan daripada perubahan sosioekonomi yang berlaku. Kelompok majoriti berasa tergugat sekiranya Rohingya atau kelompok minoriti pelarian yang lain diberikan gaji yang setara dengan mereka. Persaingan yang wujud dalam peluang pekerjaan menjadikan kelompok majoriti lebih berhati-hati. Mereka bertindak balas dengan mengawal kegiatan ekonomi kelompok Rohingya dan mengatur kedudukan Rohingya dalam bidang pekerjaan iaitu dengan memberikan pekerjaan tidak mahir yang bergaji rendah. Minoriti Rohingya menerima sikap prejudis, diskriminasi dan stereotaip yang dilabelkan pada mereka berikutan daripada kawalan terhadap sosioekonomi oleh kelompok majoriti dan kerajaan (Suan, 2006). Hal ini menjadikan mereka akur dengan kehendak kelompok majoriti. Manakala dalam aspek pendidikan, kelompok majoriti dilihat terbuka dalam membantu kanak-kanak Rohingya untuk mendapatkan pendidikan asas di sekolah swasta. Hal ini dapat dibuktikan dengan kejayaan Future Global Network Foundation (FGN) dalam membantu kanak-kanak Rohingya melalui pembukaan sekolah swasta di Selayang.

Walau bagaimanapun, hubungan antara minoriti (interminorities) Rohingya adalah utuh berikutan daripada pergantungan mereka dalam proses akulturasi budaya. Dalam menempuhi kehidupan di Malaysia, minoriti Rohingya cuba untuk berakulturasi dengan budaya di Malaysia terutamanya budaya kaum Melayu. Menurut International Rescue Committee (2018) kurang daripada 20 peratus orang etnik Rohingya kekal bertutur dalam bahasa ibunda mereka iaitu bahasa Burma. Hal ini disebabkan oleh sebilangan besar daripada mereka telah berakulturasi dengan bertutur menggunakan bahasa Melayu dan berusaha mendidik anak-anak mereka menggunakan bahasa Melayu. Pengkaji juga melihat bagaimana komuniti Rohingya di Selayang beradaptasi dengan budaya orang Melayu dari segi pemakaian, makanan dan bahasa. Menurut salah seorang daripada informan, Encik Adam (lelaki, 40 tahun), selain daripada jiran-jiran yang terdiri daripada etnik Melayu, terdapat juga majikan etnik Cina yang membantu mereka dalam menguasai bahasa Melayu komunikasi.

Selain itu, jaringan sosial yang terbentuk dalam kalangan mereka adalah penting dalam memberi sokongan di antara kelompok Rohingya. Mereka hidup secara berkongsi serta saling bekerjasama meringankan beban ekonomi dalam komuniti. Menurut Suan (2006), walaupun terdapat ketidaksefahaman antara mereka, namun jaringan sosial yang kuat telah menyatukan mereka dalam menghadapi saat-saat sukar kehidupan. Solidariti dalam kalangan Rohingya di Selayang juga utuh kerana mereka hidup dengan saling bergantung antara satu sama lain. Kehidupan dalam suasana keluarga yang besar menjadikan mereka saling bekerjasama membantu dari segi bebanan ekonomi, masalah dalam kehidupan merantau serta kekecewaan disebabkan oleh kesukaran yang dihadapi oleh mereka. Salah seorang informan iaitu Encik 
Taufiq menyatakan bahawa beliau tinggal bersama-sama keluarga Rohingya lain kerana mereka memerlukan sokongan antara satu sama lain serta memudahkan mereka untuk membantu menyelesaikan masalah yang dihadapi oleh mereka sebagai minoriti pelarian.

\section{Kesimpulan}

Kemelut konflik yang melanda di negara asal telah menyebabkan pengusiran berlaku dalam kalangan Rohingya. Mereka terpaksa meneruskan kehidupan dengan bermigrasi ke negara baharu serta berhadapan dengan reaksi negatif daripada kelompok majoriti iaitu rakyat tempatan. Namun, percubaan untuk berakomodasi, beradaptasi serta menyesuaikan diri dengan persekitaran baru telah membantu menjernihkan keadaan yang tegang terbit daripada sikap kelompok majoriti. Selain itu, pemahaman bahasa, pengaplikasian adat dan budaya, penyesuaian terhadap gaya hidup negara yang diduduki terutama dalam kalangan generasi muda membantu mengatasi rasa keterasingan yang dialami selepas migrasi secara besar-besaran berlaku. Keenamenam dimensi Kinloch telah membongkar pelbagai isu berkaitan minoriti etnik Rohingya di Selayang yang mengalami diskriminasi hak asasi manusia yang amat serius di negara asal dan berhadapan pula dengan kawalan dan sekatan di Malaysia.

Tindak balas kelompok majoriti terhadap kemasukan kelompok minoriti dalam ekonomi dan pendidikan negara menyebabkan beberapa perkara negatif muncul seperti stereotaip, diskriminasi dan prejudis. Misalnya, kelompok Rohingya yang terjerumus dalam aktiviti jenayah seperti yang dipaparkan di media massa adalah hasil daripada kekangan peluang pekerjaan dan sekatan daripada memasuki sistem pendidikan formal. Hal ini menyebabkan kelompok minoriti Rohingya tidak berpeluang merasai segala kemudahan yang diterima oleh kelompok majoriti. Bukan itu sahaja malah mereka turut distereotaip atau dilabel secara negatif dalam negara yang diduduki. Lebih memburukkan keadaan Rohingya menerima dengan mudah sikap prejudis dan stereotaip oleh kelompok majoriti terhadap diri mereka tanpa mengambil sebarang tindakan untuk mengubah keadaan tersebut. Mereka tidak kisah dianggap rendah (inferior) dan dibezakan berdasarkan ciri-ciri ras dan etnik yang menyebabkan mereka diletakkan dalam bidang kerja tertentu. Hal ini disebabkan oleh situasi mereka sangat bergantung kepada saluran ekonomi yang telah ditetapkan oleh kelompok majoriti. Keadaan ini akan menutup ruang yang baru kepada kelompok minoriti untuk mengubah kehidupan serta menyukarkan mereka untuk melangkah ke hadapan.

Oleh itu, enam dimensi kelompok minoriti Kinloch telah merungkai keadaan kehidupan Rohingya di Malaysia. Reaksi minoriti Rohingya terhadap kawalan keinstitusian di Malaysia membantu mereka dalam meneruskan kehidupan. Pengkaji berpandangan bahawa sokongan kelompok majoriti adalah penting dalam mengubah nasib golongan minoriti pelarian khususnya Rohingya. Bantuan gerakan-gerakan sosial yang ditubuhkan oleh rakyat Malaysia membantu minoriti Rohingya di Selayang untuk mendapatkan pendidikan asas di sekolah. Pengkaji berharap supaya gerakan-gerakan yang membantu kelompok minoriti ini akan sentiasa memantau keadaan mereka secara berterusan dalam pelbagai aspek termasuk pendidikan, kesihatan, keselamatan dan sosioekonomi supaya mereka tidak rasa terpinggir. 


\section{Penghargaan}

Setinggi-tinggi penghargaan dirakamkan kepada Management \& Science University (MSU) dan enam orang ibu bapa Rohingya di Selayang yang memberikan kerjasama sebagai informan kajian.

\section{Rujukan}

Australian Government Department of Immigration and Citizenship. (2006). East Timor Born. Australia: Australian Bureau of Statistics Census of Population and Housing.

Askland, H. H. (2007). Habitus, Practice and Agency of Young East Timorese Asylum Seekers in Australia. The Asia Pacific Journal of Anthropology, 8(3), 235-249.

Bernama. (2015). Sindiket Pemerdagangan Rohingya. Retrieved from http://www.astroawani. com/berita-malaysia/infografik-sindiket-pemerdagangan-rohingya-61620

Beswick, D. G. \& Hills, M. D. (1972). A survey of ethnocentrism in Australia. Australian Journal of Psychology, 24, 211-225.

Crockford, F. (2007). Contested Belonging: East Timorese Youth in the Diaspora. Tesis PhD, Australian National University.

Dali, A. M. \& Abdullah, A. (2012). Air Mata Kesengsaraan Rohingya: Identiti, Penindasan dan Pelarian. Malaysia: Inteam Publishing.

Hamzah, I. S., Daud, S. \& Idris, N. A.. (2016). Pelarian Rohingya dan isu-isu kontemporari di Malaysia. Geografia-Malaysian Journal of Society and Space, 12(9), 11-23.

Human Rights and Equal Opportunity Commission. (1999). New Country, New Stories: Discrimination and Disadvantage Experienced by People in Small and Emerging Communities. Sydney: Race Discrimination Commissioner.

Hyman, I., Vu, N. \& Beiser, M. (2000). Post-migration stresses among Southeast Asian refugee youth in Canada. Journal of Comparative Family Studies, 3, 281.

International Rescue Committee. (2018). Resettlement and The Rohingya. Retrieved from https://www.lfsrm.org/wp-content/uploads/2018/03/ResettlementandRohingyaIRC.pdf

International Rescue Committee. (2020). No time to lose: An urgent call for access to quality education for rohingya children in Cox's Bazar. Retrieved from https://reliefweb.int/ sites/reliefweb.int/files/resources/ircaccesstoeducationrohingyav4.pdf

Kassim, A. (2009). Filipino refugees in Sabah: State responses, public stereotypes and the dilemma over their future. Southeast Asian Studies, 47(1), 52-88.

Kinloch, G. C. (1979). The Sociology of Minority Group Relations. United States of America: Prentice Hall.

Lewa, C. (2009). Asia's new boat people. Forced Migration Review, 30.

Little, W. \& McGivern, R. (2012). Introduction to sociology - 1st Canadian edition. OpenStax College. https://opentextbc.ca/introductiontosociology

Medecins Sans Frontieres. (2002). 10 Years for The Rohingya Refugees in Bangladesh: Past, Present and Future. Holland: Medecins Sans Frontieres.

Pikkarainen, H. \& Brodin, B. (2008). Discrimination of national minorities in the education system. Laporan Ombudsmannen Mot Etnisk Diskriminering (DO) 2008, 2. 
Rees, S. (2004). Refuge or retrauma? The impact of asylum seeker status on the wellbeing of East Timorese women asylum seekers residing in the Australian community. Australian Psychiatry, 11(1), 96-101.

Schweitzer, R., Perkoulidis, S., Krome, S., Ludlow, C. \& Ryan, M. (2005). Attitudes towards refugees: The dark side of prejudice in Australia. Australian Journal of Psychology, 57(3), 170-179.

Skeels, A. (2012). Refugee children's participation in protection: a case study from Uganda. Research Paper Centre for Migration Policy Research, Swansea University United Kingdom, 241.

Suan, T. P. (2006). Kehidupan Rohingya di Malaysia: Perjuangan dalam ketidakpastian hidup. Akademika, 68(1), 111-122.

The Equal Rights Trust (ERT). (2010). Trapped In A Cycle of Flight: Stateless Rohingya in Malaysia. UK: ERT.

UNDP. (2018). Impacts of the Rohingya refugee influx on host communities. Retrieved from https://issuu.com/bdundp/docs/impacts_of_the_rohingya_refigee_inf

UNHCR. (2020). Figures at a glance in Malaysia. Retrieved from https://www.unhcr.org/ enmy/figures-at-a-glance-in-malaysia.html

Walker, I. (1994). Attitudes to minorities: Survey evidence of Western Australians' attitudes to Aborigines, Asians and women. Australian Journal of Psychology, 46(3), 1-7. Retrieved from https://www.researchgate.net/publication/313136705_Attitudes_to_minorities_ Survey_evidence_of_Western_Australians'_attitudes_to_Aborigines_Asians_and_wome $\mathrm{n}$

Yoshikawa, L. \& Teff, M. (2011). Malaysia: Invest in Solutions for Refugees. Washington: Refugees International. 